\title{
Can trade unions become environmental innovators? ${ }^{1}$
}

\author{
Nora Räthzel, David Uzzell, Dave Elliott
}

\section{Learning from the Lucas Aerospace workers}

The attempt by workers at Lucas Aerospace in the 1970s to develop a plan to convert production in their company from weapons to socially useful goods has recently been invoked in debates on creating low-carbon societies. ${ }^{1}$ As Hilary Wainwright and Andy Bowman have argued, a renewed Green New Deal that involved a similar level of painstaking attention to grass-roots participation 'would be a worthy successor indeed'. ${ }^{2}$ We agree with this view, and we would like to make the additional argument that the Lucas example is particularly helpful for international trade union debates on climate change.

The Lucas workers were way ahead of their time in recognising the need for sustainable development - even if such a concept did not exist at that time. But their project also demanded a radical revision of the ways in which society determined its priorities. In today's terms, their argument was for a 'Just Transition'. In other words, in adapting production for different needs, it was important to make sure that any new strategies would take workers' interests into account. And it is this notion that is important in trade union debates today. ${ }^{3}$

Trade unions are not commonly regarded as being on the frontline of the climate change battle. Many people (including not a few trade unionists) see unions as being on the side of climate sceptics, or as being a constituency for whom other concerns are more important. But many national and international unions are currently seeking to develop policies through which their industries can help to mitigate the causes and effects of climate change; and unions do have a long history of struggling for environmental issues - even if this history is not given so much attention today. For example, in the early years of industrialisation trade unionists fought against air and river pollution in their communities. Furthermore, it should not be forgotten that safe workplaces - an issue where the history of trade union involvement is more familiar - are also an environmental issue. One reason why the trade union record is often overlooked is that environmental issues have often been raised by environmental movements, which have paid little attention to social and work issues. Equally, trade unionists often reject environmental arguments, for example claiming that it is more important to preserve and create jobs than to 'save a few trees' - as was the kind of dismissive remark sometimes made in the course of our interviews. However, things are changing dramatically and fast.

\section{“Just Transition"}

The most recent example of trade unions playing a key role in climate change internationally was at the negotiations at the Copenhagen climate summit in 2009, where 400 trade unionists from all over the world were present. Apart from lobbying

\footnotetext{
${ }^{1}$ Räthzel, N., Uzzell, D. and Elliot, D. (2010) 'Can trade unions become environmental innovators?', Soundings, 46, 76 - 87
} 
their governments to support the inclusion of a 'Just Transition' clause into the negotiated document (which was successful until the very end, when the conference ended without an agreed document), the International Trade Union Confederation (ITUC) and LO-Denmark organised 28 workshops and symposia in the World of Work Pavilion. Among the many themes discussed were: conversion in Japan; green jobs in India; low carbon industrial policies in Europe; women workers and green jobs; climate justice; sustainable transport policies in Spain; challenges for the power generation sector; the role of public services. More than 1000 people attended these events, which were eloquent testimony to the high level of awareness of trade unionists, and the readiness of unions to act. It is indeed predominantly the international unions especially the ITUC, but also the International and European Transport Workers Federations (ITF and ETF) - that have developed platforms for combating climate change that can measure up to the initiatives of 'proper' environmentalists. Last year the International Metalworkers Federation (IMF) formulated its position for reducing emissions, and in August 2010 the ITF had a one-day global conference on the issue of Climate Change, where it adopted a very ambitious document. ${ }^{4}$

Equity, justice and solidarity in the fight against climate change is the principal policy statement of the ITUC. 5 This document was drawn up after extensive discussions with its 311 affiliates in 155 countries, following work undertaken by the ITUC Task Force on Climate Change, established in December 2007. The danger of such a document is that it resorts to representing the "lowest common denominator". However, the ITUC sought to find the most ambitious position, even though one affiliate opposed it. It argued that it was necessary to demonstrate leadership by adopting a position that showed where unions could be in the future, not necessary one where all unions agree already. The report provides a comprehensive outline of the problems facing workers in respect of mitigating climate change, across all sectors of industry and across the North and South.

As noted earlier, the central plank of ITUC policy is the concept of just transition: 'Trade Unions will work towards the transformation of all jobs into environmentally-friendly and socially-decent jobs. Green jobs are a first step towards the transformation' (p12). The policy priorities are summed up as the need 'to create green and decent jobs, transform and improve traditional ones and include democracy and social justice in environmental decision-making processes' (p10). In our discussions with different unions, however, it became clear that the 'green jobs' element of just transition is not unproblematic. A Canadian delegate argued that green jobs was 'a term from the environmental movement, not the labour movement' (ironically, the term was originally formulated by the Canadian trade union movement). This suspicion towards 'green jobs' was expressed even more strongly by another interviewee, who - capturing the views and position of one strand of thinking within the unions - saw the traditions of his industry and the identity of its workforce being challenged by the notion of greenness:

Green jobs are insulting. Steel are brown jobs. You can't build windmills and aircraft without steel - the steel job is a green job. A rigger is a rigger when he is working in a brown or green job. What is a green boss? A green boss is still a boss. A green capitalist is still a capitalist? Vestas - they might be green, but they are still bastards, and still bosses. ${ }^{6}$ 
The main aim in the ITUC text is to suggest policy measures that will lead to a transformation of the world economy, towards a new, environmentally sustainable production system. That some jobs will have to disappear or be radically changed in order to create this new system is a point of departure - not a possibility that might be avoided. In its document What's Just Transition? it argues:

We need to transform the economy; we therefore ask for a process aimed at transforming every economic sector into a sustainable one. The international trade union movement is committed to supporting ambitious actions aimed at combating climate change while shifting growth towards a truly sustainable development, where social welfare and broader environmental challenges are also addressed. Just transition is a tool the trade union movement shares with the international community, aimed at smoothing the shift towards a more sustainable society and providing hope for the capacity of a 'green economy' to sustain decent jobs and livelihoods for all. ${ }^{7}$

The ITUC also notes that specific industries are likely to see the most profound transformations:

Certain sectors, such as those linked to fossil fuel energy and other energy intensive sectors will face significant changes in the global shift to a low carbon energy and industrial future. This includes industries such as steel, iron and aluminium, fossil fuel-based power generation as well as energy intensive services, such as road transport. It is of utmost importance to support investment in low carbon technologies and energy efficiency measures, retaining and developing viable low carbon industries, wherever possible, supported by skills and training programmes for a low carbon, resource efficient economy.

When risks for certain sectors are unavoidable, measures must be taken in consultation with trade unions, to protect the most vulnerable in the production chain: the workers (p15, Equity, justice and solidarity in the fight against climate change).

It is understandable that such formulations provoke the resistance of workers in these industries. A leading representative of the IMF explained their position:

Well, we have a bit of a discussion at the moment with the ITUC. And when I say 'we', I mean the industrial trade unions. And the reason for that is that the prime focus of the ITUC work at the moment appears to be around this whole question of Just Transition. And we think it should be about emissions. So there's a little bit of a gap there. And it's partly our responsibility, because I think the ITUC have viewed this whole process as a political issue, whereas we view it as an industrial issue. And in a way we've woken up too late to the debate. So now we're trying to push to refocus the debate.

The term 'industrial issue' indicates activities whereby emissions are reduced through technological measures. But the ITUC document recognises that improvements in technology and changes in production methods will be insufficient, and that in addition to such measures people's way of life will have to change, as well as the societal model on which production is based. It upholds the notion of a 'fairer, environmentally 
responsible society that respects human and labour rights' (p8), and calls for a holistic approach to the way in which society and production processes are organised.

The just transition concept partly provokes resistance because it envisages major processes of transformation, and this always creates anxieties (especially given the insecure working conditions that neoliberalism has already brought about); but resistance also stems from the frequent representation of workers as mere victims of these changes. Transformations are presented as objective necessities, arising solely from the need to protect the environment and mitigate/adapt to climate change. It is not equally stressed that transformations are also in the interest of workers themselves - in their interests as citizens, but also in their interests as workers benefitting from safe, socially useful and high-quality jobs. 'Decent work' is a central demand of unions, and it forms part of the Just Transition documents. This demand is formulated as the need to protect workers from inhumane working conditions and job insecurities. Protection is of course an essential part of the work of trade unions, but when workers are defined as 'the most vulnerable in the production chain', their pride and sense of worth can be offended. If policies do not grant them a status as actors/subjects in their own fate, workers become suspicious. Such an approach may serve to reproduce the alienation they already experience in the workplace: not being in control but being controlled. They are likely to experience the just transition process in a similar way - as something that happens to them instead of being developed by them. We suggest that this is one of the reasons why workers sometimes see environmental policies as a threat. Our Brazilian interviewees expressed this most clearly. They argued that the environment is presented as a threat, as something that hinders economic development, as opposed to an opportunity that can create new possibilities for workers to broaden and develop their skills. But in the discourses of environmentally concerned unionists there is a tendency to present workers either as victims in need of protection or as objects of education.

\section{The Lucas project: self-organisation for change}

The struggle of the Lucas Shop Stewards Combine Committee for alternative production offers a host of insights and perspectives that could help overcome the suspicion with which many workers and unionists regard environmental policies - including those of their own unions. The next part of this article therefore consists of relevant extracts from our interview with Dave Elliott, who was involved with the Lucas plan from the earliest stages (the entire interview can be found on the Soundings website: www.lwbooks.co.uk/ReadingRoom/contents.html).

In the early 1970s, UK government defence cuts, as well as the support of the Labour government for the 'consolidation' of the UK's military industries, led to plans by Lucas Aerospace that would make 13,000 workers redundant in its seventeen factories.

The Lucas workers leaders said: 'Well, this is fine. We support the defence cuts, you know. On the other hand, our jobs are there' - most of the aerospace jobs, about half, would be defence-related. 'Job loss is our problem. I know (...) management doesn't care whether he sacks half its workforce. Presumably it'll start up another factory in Brazil or something, you know! But we do care. And we've got a vested interest in maintaining our jobs'. 
The situation in which the Lucas workers found themselves is similar to what can occur as a result of environmental measures. Jobs were at risk - or at least companies argued that jobs were at risk. And as with changes currently associated with climate change prevention, they thought defence cuts were basically a good thing, but they also knew they would not be able to influence the government's decision. So they decided to try another way. Instead of fighting for the maintenance of the defence related jobs, they started the struggle for the transformation of production at Lucas from military hardware to socially useful products.

So what they did was survey the physical assets, what the plants had in terms of tools and machines ... and what skills they had. And they did a sort of Doomsday Book detailed assessment of all the assets ... 'Cos the shop stewards on site - they know everybody. They're the sort of people that wander round the factory as of right - they can very rapidly build up a picture of the company. And they did a sort of audit of the company.

And then they sent a super-suggestion scheme around all the factories, invited everyone to put in proposals. Has anyone got any pet projects which they'd thought of, which they wanted? And all the little old grey-haired engineers from Burnley came forward with, you know, a little box file with lots of yellow documents: 'Well, I did this when I was 25'. Hundreds of ideas came out. I mean, some of them were crazy; but some of them were not crazy. Some of the younger ones were obviously up to speed. I mean, some of these workers were top-end of the aerospace high-tech front -these were people as advanced technically as you'd get anywhere! So they got in touch with me and a few other academics. And we got into various smoke-filled rooms and had big meetings. And this was really challenging for me, because at that time the sorts of things people were talking about were hippyesque stuff, basically: you know, Welsh hill farms, small wind turbines, micro-hydro, a bit of solar collected on the roof, and bio-gas - all really nice cuddly small-scale technology. And the Shop Stewards Committee, you could tell, were not going to be impressed - 'What!' No, no, no, no! So I had to dig a bit deeper. I had lots and lots of stuff. I put it all together and produced this document, putting together all these ideas but retranslating it away from the fringe small-scale stuff. And electric vehicles were the sort of thing we'd come up with ... Mike [Cooley] would go around hospitals and say, 'Look, this guy is going to die within six months 'cos they haven't got enough kidney machines. We could knock one up in half an hour - you know, our engineers could solve all these problems overnight!' And for the people hobbling along with canes and walking sticks - 'With our tele-cheric systems, we could have a tele-cheric remote arm/leg system put together! We know how to do this!'.

This was a strategy that built explicitly on the complementary skills and competences of workers, engineers and shop stewards. In this way, the threat of job loss could be turned into an opportunity for workers to realise their potential, some of which had been dormant for a long time, or had maybe not been recognised in terms of being a financially viable option (some workers drew on their personal hobbies and sought to integrate the skills learnt in their private and professional lives). One of the reasons why it was possible to engage workers and engineers in the process was that the Lucas shop stewards managed to overcome the division between white and blue collar workers: 
... the Lucas shop stewards decided the only way to organise in the future was across all trades and across the whole combine, all seventeen factories. So the white-collar and blue-collar workers' unions sort of grudgingly decided to join together - which, believe me, is no easy thing, because each factory had a long history of separate unionism between engineers and white-collar workers. But the Combine Committee managed to get them together on each site and then across the whole thing - hence the words Shop Stewards' Combine Committee.

This is an important element to consider: grassroots initiatives are vital, but it is equally essential to create forms in which workers on the floor and technicians and engineers inside and outside factories can work together to develop alternative forms of production. As well as using a comprehensive approach to include white- and bluecollar workers in the process of developing alternative products, the Combine Committee also recognised that they needed the support of the workers in all the factories in order to negotiate with management to implement their suggestions:

So the next thing to do was to put it to the workforce. So they held meetings on every site, and said, 'Look, you know we've had meetings before about wage bargaining. You know, we're going to put a 5\% wage claim in. Well, there's a new one! You know what the company says, that the reason for the redundancy problem was the Labour government's decision to throttle back on defence spending (...) Now, we always agree with cuts in defence, but obviously we need something to replace it. So these social projects, socially useful projects, you know, are the ones that we're recommending' - that 'are you with us?' sort of thing. And it got overwhelming support. They said, 'Well, this may get nasty, because management may not accept this stuff, you know. We know they always talk about suggestion schemes - these boxes in a corridor with cobwebs on that you put things in! But we're doing that really now, on a large scale. On the other hand, what we're doing is telling the management what to produce in their factories, and they won't like it!' 'So we may have to use industrial muscle to back it up. So would you be prepared to take industrial action on the basis of the plan?' Most people said, 'Yeah, what's the alternative? Well, we're out the door.' They said, 'Yeah, okay, we'll do that!' So off they trot to the management. They present it across the two-sided negotiating table, and the management was trying to put round tables in, but they said, 'We want the square table! That's decided!'.

It is not as if there are no technical suggestions from unions today on how to develop environmentally sound production systems with less carbon emissions. The Swedish metal workers' union and the Danish union of technicians, as well as the TUC and the CCOO, for instance, have produced documents for 'greening' workplaces. And to a certain degree they have also been developed in consultation with workers. For instance, in 2009 the TUC conducted a survey among shop stewards asking them about health, safety and environmental policies in their workplaces. However, the questions predominantly tackled working conditions, not the products that were produced. In contrast to this, the suggestions of the Lucas Combine Shop Stewards' Combine Committee were meant to transform the existing production process, producing different kinds of products. 
The motivation for the plan did not lie solely in the need to protect jobs but also in the satisfaction to be derived from producing socially useful products - useful for people and the environment. As Elliott recounts:

... at the beginning of the Corporate Plan, it said: 'If the company could guarantee us jobs on aerospace and defence systems, fine'. However, workers would also say: 'if it's my choice, I'd rather be working on things that would help people rather than things that kill people - wouldn't anybody!'.

The same could be said in relation to the environment. If people had the choice they would rather produce in a way that helps the environment and people, instead of things that are destructive to both.

The Lucas project, though influential with unions and governments all over the world at the time, in the end failed. An obvious reason was that the workforce were challenging the management over the right to determine what should be produced. In addition it is noteworthy that, far from providing support and encouragement, 'the trade union bureaucracy (...) converged to undermine what they perceived to be an oppositional movement'. ${ }^{8}$ Equally, they received little support from the Labour government, and when Thatcher came into power the position of trade unions in general was undermined. Today, the conditions for such a project might be more favourable, since there is wide recognition of the need to combat climate change.

Cooley identifies four major contradictions that 'highlight the problems of our supposedly technologically advanced society' (Architect or bee, p114). These are: the gap which exists between what technology could provide for society and what it actually does provide; the tragic waste our society makes of its most precious assets the skills, ingenuity, energy, resourcefulness and enthusiasm of its people; the myth that technology as such will free people from routinised tasks allowing them to be creative and fulfilled; and the hostility of society at large to science and technology, and thus to scientists and technologists, whom they see as creators of Frankenstein inventions, ignoring the fact that it is not technology that is the problem, rather that such developments are driven by profit rather than need. These four contradictions impacted on the workforce and unions at Lucas Aerospace, and the Lucas Plan was the outcome.

Climate change has brought such contradictions even more sharply into focus, and made projects like the Lucas Plan a necessity. The threat of climate change requires a collective response, and trade unions are critical to this process. They have a long and proud history of acting collectively. Even when new technologies can assist in reducing carbon emission, experience suggests that workers are usually the losers, either through redundancies or the creation of jobs that might be green but are not necessarily decent. Unions therefore have an interest to intervene in these processes. Unionists are consumers as well as workers, and what they do in the workplace has an impact on the home, the wider community and workers in other parts of the world.

However, there is a gap between the interests and abilities of unions and the actual support for environmental policies among their members. We believe that drawing on the Lucas experience - trusting in and building on workers' skills and desire to produce 
something useful for themselves and the environment, developing strategies with workers (technicians, and academics), instead of for them - would create a greater chance for the realisation of socially and environmentally just policies.

David Uzzell is Professor of Environmental Psychology at the University of Surrey. Among his recent publications is (co-authored with Nora Räthzel) 'Changing Relations in Global Environmental Change', Global Environmental Change, 19, 2009. Nora Räthzel is Professor of Sociology at the University of Umeå, Sweden. Among her recent publications is (co-authored with David Uzzell) 'Transforming Environmental Psychology', Journal of Environmental Psychology, 29, 3, 2009. They are currently establishing the International Centre of Environmental Labour Studies (ICELS). Dave Elliott is Professor Emeritus of Technology Policy at the Open University. Among his publications is Sustainable Energy: Opportunities and Limitations, Palgrave 2007. He is also editor of Renew, which seeks to disseminate information about sustainable energy technologies: www.natta-renew.org.

\section{Notes}

1. The Lucas Shop Stewards put forward an alternative corporate plan for peaceful production, which was part of their long campaign against job losses. For a good account of the history of the plan see Hilary Wainwright and David Elliott, The Lucas Plan. A new trade unionism in the making?, Allison \& Busby 1989.

2. H. Wainwright \& A. Bowman, 'A real green deal', Red Pepper, October/November 2009: www.redpepper.org.uk/A-real-green-deal.

3 . The following discussion of these debates draws on our research project to investigate the ways in which unions are seeking to engage with the issue of globalising work divisions and globalising environmental change. In the course of this research we conducted an extensive interview with Dave Elliott, co-author of The Lucas Plan (see note 1). Listening to his incisive account of the ten-year long struggle it became clear to us how valuable this experience was for creating effective strategies to combat climate change today. The Research project was financed by FAS (Forskningsrådet för Arbetsliv och Socialvetenskap - the Swedish Research Council for Working Life and Social Research). It is still in progress and we have so far conducted 28 interviews comprising some 60-plus hours of recordings with trade unionists in international (ITUC, ETUC, IMF, EMF, ETF, and ITF), national as well as local unions (in the UK, Sweden, Spain, Malaysia, Singapore and Brazil). All interviews quoted in the text are from this research. 4. See www.itfglobal.org/news-online/index.cfm/newsdetail/4838.

5. ITUC, Equity, justice and solidarity in the fight against climate change, International Trade Union Confederation 2009a: www.ituc-csi.org/IMG/pdf/climat_EN_Final.pdf. 6. This was a reference to the dispute at the Vesta wind-turbine factory on the Isle of Wight, UK in 2009. See G. Gall, 'Striking workers learn to think green', Guardian, 22.7.09: www.guardian.co.uk/commentisfree/cif-green/2009/jul/22/vestas-wind-factoryenvironment.

7. ITUC, What's Just Transition? A Just Transition a Fair Pathway to Protect the Climate International Trade Union Confederation 2009b, www.ituc-csi.org/what-s-justtransition.html.

8. M. Cooley, Architect or bee: the human price of technology, Hogarth Press 1987, p17. 